\title{
CIRCULAR MOBILITY AND NEO-PAGANISM (ESTONIAN CASE)
}

\author{
Ekaterina Anastasova \\ Institute of Ethnology and Folklore Studies with Ethnographic Museum, \\ Bulgarian Academy of Sciences \\ e-mail:ekaterina_anastasova@yahoo.com
}

\begin{abstract}
In recent years, numerous papers related to what is known as migration studies have been written. I would like to point out right away that this particular article does not belong to that stream of papers. It has rather been "brought to life" by a number of other factors. I consider as an example a story of the post-socialist migrant, using mobility between Estonia and Scandinavia after 2000, within the context of the search for the "national" not only as an "image" or a "narrative", but also as a migration strategy.
\end{abstract}

Keywords: Estonia, migration, neo-paganism

In recent years, numerous papers related to what is known as migration studies ${ }^{1}$ have been written. I would like to point out right away that this particular article does not belong to that stream of papers. It has rather been "brought to life" by a number of other factors.

On the one hand, there has been a tendency towards the research of migration diasporas ${ }^{2}$ from the perspective of the "national" as an institutional structure, which is predominant in Bulgarian literature. As a rule, this particular approach replicates studies of minorities' "revival" after the 1990s, the studying of which follows the paradigm of structuring the nation, as it has been displayed 
in a number of papers (for example, see Gossiaux 1996: 191-198; Anastasova 2008: 5-10). When applied to a diaspora, it comes down to researching the institutions to which the diaspora is related (an embassy) and the ones created by it (a school, a church, mass media, etc.) in the process of adaptation to a foreign state (Penchev 2016). As a rule, some part of a diaspora is considered, and it is either in chronological terms (traditional, before/after the Second World War, socialist, post-socialist, etc.) or on account of some other distinctive features (professional, social, sexual, etc.; for example, see Krasteva 2014). Thus, a diaspora can be characterised as an isolated community (or a group), in accordance with the multicultural approach, which brings its national/ethnic features to a new country (at least some souvenirs from their homeland to a new home abroad). It is represented by an isolated community, which exists "on its own", preserves its traditions, and has limited contact with the macro-society that has no effect on it. It seems as if under any other approach a diaspora (if it even perceives itself as a community) could be considered as a group of individuals who create their own individual strategies of adaptation and integration. The latter are related to different circumstances pertaining mainly to the relations with the local population and the position of an individual / a group in the macro-society. However, naturally, this does not mean that no typological or universal features exist. This attitude is rather related to an intercultural approach $^{3}$ which considers both the role of an individual in migration processes and his or her interaction (or the interaction of a group) with the society in the recipient country. Obviously, in terms of methodology, a case study would probably be the most suitable method to be used in this respect, i.e., the study of the most significative cases that demonstrate individuality, predominant features, and the variability of the processes of adaptation/integration in the context of migration. Would those "cases" be representative? Maybe they would (since every single individual represents a kind of a social class), but even if they would not, they would contain a story and imagination, rich in cultural associations, structuring the image of "a national" and "a national narrative" in the context of migration. It can also be assumed that they would hardly be identical to the prism of institutes, which creates something like a "set" of features, including folklore, celebrations, food, and memories about the homeland.

On the other hand, the paradoxical development of "democratic changes" after the 1990s has provoked a search for unique features in the nature of minimum migration from the Socialist Bloc to the West (before the 1990s), 
and within the migration flow, accounting for millions of people arriving from the countries of Eastern Europe that were "free" already. ${ }^{4}$

Ronald Skeldon believes that migration is the outcome of inter-relations between the level of economic development, the level of the formation of the state (nationhood), and the characteristics of the mobility of the population. Hence states with moderate social, economic, and infrastructural development force people to emigrate (Skeldon 1992: 52). Economic and social instability as well as the "abdication of the state" (in accordance with the popular media cliché existing in Bulgaria, while the claims laid against the authorities in different Eastern European countries are quite similar) determine the exceptionally labour-related nature of the post-socialist emigration flow, in which there have been considerably fewer white-collar workers ${ }^{5}$ than so-called blue-collar ${ }^{6}$ ones (in terms of their self-fulfilment in the recipient state). The following question arises in this perspective: how is identity related to the perceptions pertaining to the "national" structured in a socialist or a post-socialist emigrant?

Thirdly, the issue of immigration and mobility is very peculiar, presenting two possible strategies in the perspective of the "national". ${ }^{7}$

Hereby I consider as an example a story of the post-socialist migrant, using mobility between Estonia and Scandinavia after 2000, within the context of the search for the "national" not only as an "image" or a "narrative", but also as a migration strategy.

I would like to offer a more nuanced interpretation of post-socialist ${ }^{8}$ migration to the West, which could represent different aspects of the search for "roots", and correspondingly, the structuring of the identity of a post-socialist migrant, on the one hand. On the other hand, I would like to present the role played by national mythology (a national story), generating the image of the homeland (the donor state) in the process of selecting one or another form of migration. This article was written on the basis of field studies carried out by the author in the Baltic states in 2013-2016, and, in particular, one specific study carried out on the Island of Muhu in Estonia in 2013.

Recently scientists doing folklore studies have been winning more projects under the European and national programmes than natural scientists.

I strongly believe that today people need folklore much more than chemistry. ${ }^{9}$ 
Estonia is one of the "high achievers"10 in Eastern (North-Eastern) Europe, who joined the European Union and NATO in 2004 and has been a member of the Schengen Agreement since 2007. A quick overview of its history reveals the existence of a number of cornerstones that still determine the predominant cultural elements of the nation.

In the $13^{\text {th }}$ century, the territory of modern Estonia was conquered by the Livonian Order (a branch of the Teutonic Order), and the Germans ruled these territories in the following centuries. In the 16th century, the country went through the Reformation, and Protestantism became the main confession. At the same time, as a result of numerous wars, some parts of Estonia were taken over by Sweden, and later on by the Russian Empire (1721). After the dissolution of the Russian Empire in 1918, Estonia claimed its independence, and the War of Independence led to the signing of the peace treaty between the Republic of Estonia and Soviet Russia in 1920. Estonia was independent until 1940, when it was occupied by the Soviet army (after Molotov-Ribbentrop Pact) and became one of the republics of the USSR. From 1941 until 1944, the country was occupied by Germany, after which it was incorporated into the USSR. In 1990, Estonia restored its constitution, and in 1991, declared its independence.

Thus, it can be concluded that there have been several major influences affecting local culture, namely German, Swedish, Russian, and Soviet. Not much is known about the ancient history and culture of the Aesti.

Along with some democratic transformations, a number of significant changes took place in Estonian society, starting from a complex situation with the Russians in the country and "getting rid of the Soviet past", and up to such "accompanying phenomena" as economic recession, unemployment, and social instability. ${ }^{11}$ In spite of that, the Estonians have been able to find ways out of very difficult situations for the sake of their independence. Alongside the anti-Soviet discourse and the "fight against monuments" (see information about a notorious story about the relocation of a monument to Soviet soldiers in Tallinn, e.g. Vukov 2009: 58-65), the nostalgia for the USSR manifests itself not only in memories about the social stability of the socialist "super-state", but it also turns into an artefact that often takes on funny shapes (for example, the series of socialist chocolates ${ }^{12}$, socialist souvenirs, etc.).

One of the most significant post-socialist phenomena for a country as small as Estonia has been emigration. ${ }^{13}$ In the result of migration processes, the population of Estonia diminished from 1,570,000 people in 1991 to 1,315,944 
people in 2016. ${ }^{14}$ The main points of destination preferred by the Estonians have been the countries of Northern Europe (the most numerous migration has been to Finland, also Scandinavia (Sweden, Norway, Denmark), and Great Britain). The main form of migration between Estonia and these countries has been what is known as circular migration ${ }^{15}$ - regular legal mobility (back and forth) between the donor state and the recipient state, or a "typical transnational way of life" (UN, Economic and Social Council - ECE/CES/2014/3016). Due to some obvious reasons (the opening of the borders, the fact that employed foreigners lack a social insurance number, and the absence of a state organisation responsible for the emigrant labour statistics, illegal labour, etc.), it is very difficult to monitor this type of migration. Some specialists observing migrations between Estonia and Finland (the most popular point of destination among the Estonian migrants) have pointed out that quite often people "do not know themselves where they would really like to settle down" (Zaiceva \& Zimmermann 2008; Levitt \& Jaworsky 2007). In spite of that, it has also been pointed out that transnational mobility between Estonia and Finland has been increasing (ECE/CES/2014/30: 13).

When staying in Estonia within the framework of a short-term field study, it is quite difficult to arrange a meeting with Estonian emigrants who have returned home. In 2013, within the framework of research dedicated to the religious commitment of Estonians living on the islands in the Baltic Sea, I was lucky enough to meet one Estonian lady who spends her winters in Norway, while coming to one of the villages on her home island of Muhu for the summertime. ${ }^{17}$ Piret ${ }^{18}$ was about 55 years old and a former medical worker, who left Estonia after she had been made redundant at the local hospital in the middle of the 2010s. She continued her employment in Scandinavia in a company engaged in apartment cleaning.

It should be pointed out here that Muhu is a very peculiar island, which welcomes hundreds of tourists from Estonia, the Scandinavian countries, and the republics of the former USSR (especially from nearby Saint Petersburg, whose inhabitants are in the habit of renting summer houses in the Baltic states in summer). The island has preserved its traditional appearance, especially Koguva village, which represents a fully preserved fishermen's village. This island is the homeland of the classical Estonian writer of the Soviet period, Juhan Smuul (Schmuul), whose monument stands by the sea (it was relocated from Tallinn in 2006), while his house has been converted into a museum. There are 


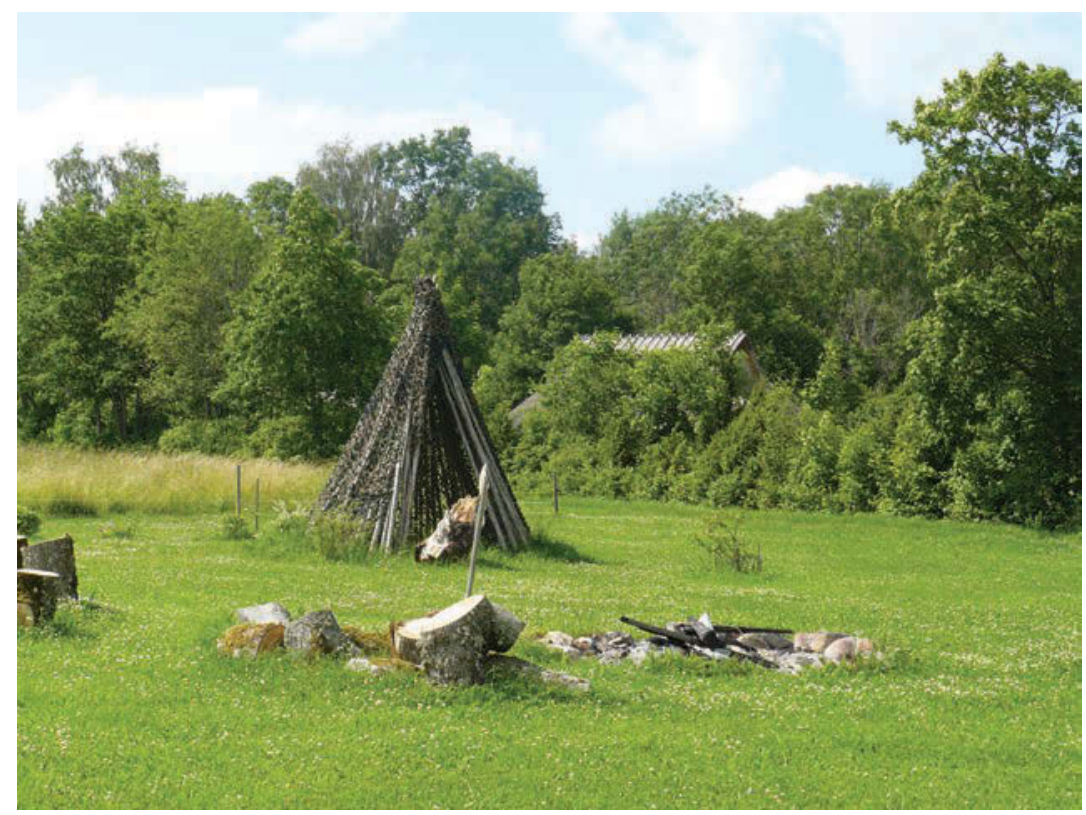

Figure 1. Piret's Sacral Place (koda). Photo by Ekaterina Anastasova.

several villages and farmhouses on the island. The island still reveals traces of ancient history, presenting castle ruins, stone graves (from the end of the first millennium $\mathrm{BC}$ to $\mathrm{AD})$, the medieval St. Catherine's Church (12 ${ }^{\text {th }}$ century), windmills, the ethnographic museum, etc. Muhu also has some connections with the processes of European integration; namely in 2012, the Fishing Museum was set up, supported by European funding. All in all, Muhu is a "folklore village" in which local ethnography and folklore (dwellings, settlement, crafts, handicrafts, songs, tales, etc.) have turned into a way of life, which is displayed to visitors and tourists by the locals with great pleasure (and for a charge). ${ }^{19}$

Piret's house and the yard represent an authentic image of the traditional Estonian way of life. The main dwelling house is decorated in the manner of a traditional barn. In the yard, there are several outbuildings, a stone fence (according to local beliefs, these stones protect the inhabitants from evil spirits), wooden idols in the garden, and an archaic koda (a summer kitchen that 


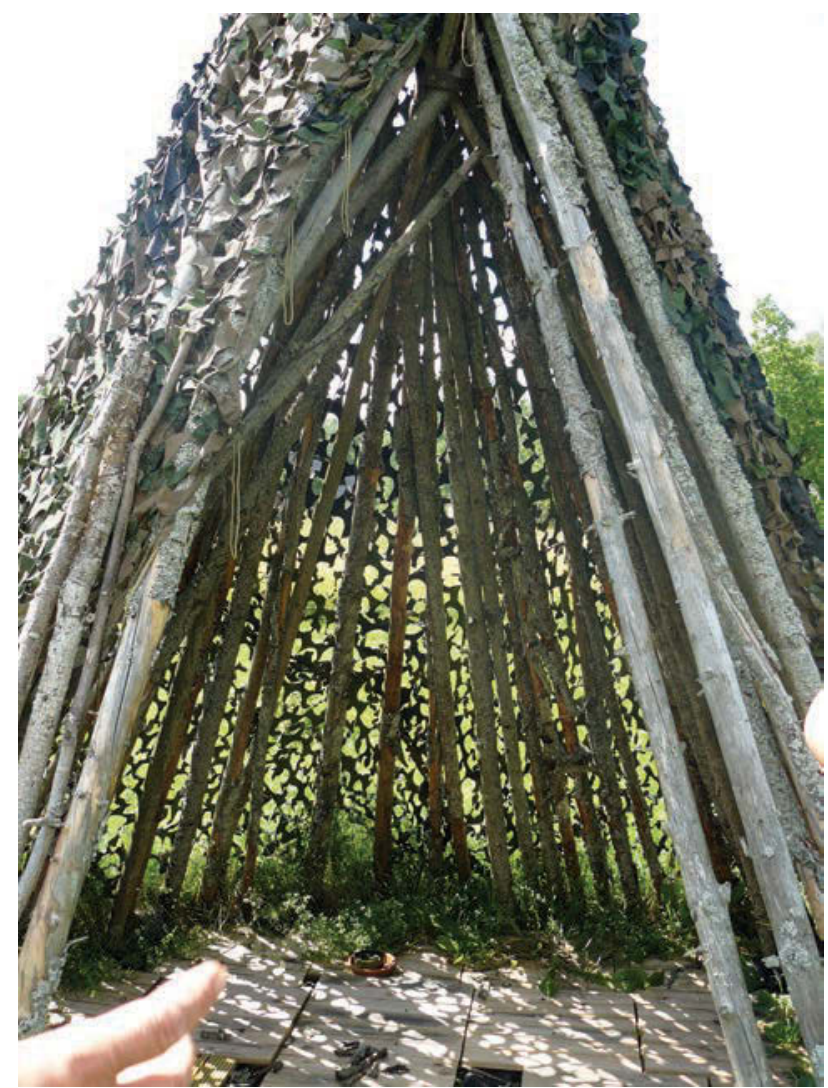

Figure 2. Inside the Sacral Place. Photo by Ekaterina Anastasova.

is used as a fisherman's hut on Muhu Island). Her house is located just a few steps away from an archaeological site, which is referred to by the locals as "sacrificial stones". These are huge roundish stones with dents in them, in which the locals would leave gifts, according to local beliefs. Today it is still believed that these stones have magical powers, which give health and well-being (there are about 1,700 similar stones in Estonia, and about 500 of them are referred to in legends and beliefs, while a hundred stones are protected by the state as 
archaeological sites). People still leave money, candles, and other small items in the dents on these stones.

Piret spends eight months a year in Norway and comes back to Estonia for the remaining four months (from May to September). She welcomes tourists and visitors from Norway and other Scandinavian countries into her house, attending to them herself. She has a garden and a small greenhouse, and also a few sheep. Piret is planning to come back to Estonia for good when she gets old.

The most interesting building in her household is the koda, which she refers to as a cult structure, where only the lady of the house can enter. This is where she prays and holds special rituals in honour of her guardian spirit. This holy place took its beginning after lightning had struck a huge old tree in the yard, which fell down on the house, doing some serious damage (almost dividing it in two), but no one got hurt. This occurrence stimulated her faith, and she built a sanctuary of her own to hold daily rituals.

But who or what does Piret believe in? She barely answered this question, nor did she name the spirit or told us anything about her rituals. She allowed us to look inside, and we saw several charred tree branches, which made us think that she burned something in there while saying her prayers. Piret emphasised that this was very personal and should not have been discussed or recounted.

Basically, in the context of the mysterious Muhu and the characteristics of Estonian mythology, Piret's faith can be reconstructed. As has already been mentioned in the beginning, we do not know much about the life and religion of the Estonians before the $13^{\text {th }}$ century. Some individual data about the beliefs of Estonians can be found in chronicles and manuscripts, but mainly they are reconstructed on the basis of materials collected in the $19^{\text {th }}$ century and Kristjan Jaak Peterson's ${ }^{20}$ translation of Finnish Mythology by Cristfried Ganander ${ }^{21}$. Friedrich Robert Faehlmann, the founder of the Estonian Learned Society, published folklore texts, including legends and mythology. He wrote a draft of the Estonian epic in prose, which later became the basis of the Estonian national epic. ${ }^{22}$ In 1925 the Taarausk (The Faith of Taara) organisation started its activities. Taara is perceived as a deity that is known in one of the Livonian chronicles as a supreme deity from Saaremaa, an island next to Muhu. A new branch of Estonian paganism started in the 1980s - Maausk (The Faith of the Earth), forming an organisation called Maavalla Koda (1995). Today, it incorporates the covens from different regions of Estonia; they have relations with pagan communities outside of the country. Their faith is defined as a unity 


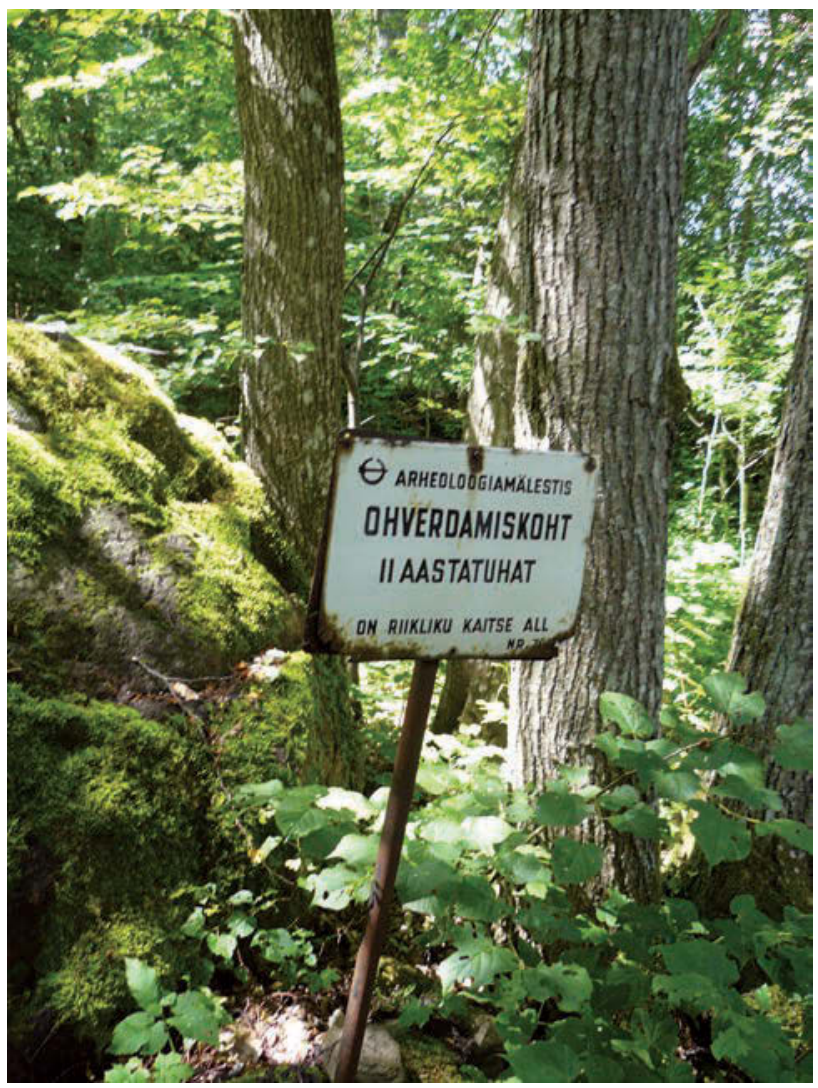

Figure 3. Sacral Stones. Photo by Ekaterina Anastasova.

of "the faith of Taara" and "indigenous Estonian religions", as "everything the Estonians have been believing in throughout the last 800 years of history and thousands of years before that". The calendar of Maavalla Koda dates back more than 10,000 years (the foundation year of the organisation is marked to be 10,208/1995), from the moment of the "Birth of the Estonian Land" (it is believed that it emerged in the result of the retreat of a glacier). Religion is animistic and local, i.e., every single locality has its own deity or spirit which cannot be removed or relocated. The main places of worship are sacred groves 
(hiis), sacrificial stones, springs, and trees. Even though some holy sites are already under state protection (as archaeological sites), the organisation is still discussing options for their preservation with the state. From time to time, conflicts arise in connection with the erection of infrastructure facilities. The main goal of this organisation is "to provide every single Estonian, regardless of his or her opinions or beliefs, with an opportunity to take pride in the religion of his or her ancestors". ${ }^{3}$

It is quite peculiar that in 2000 , statistics registered $18 \%$ of believers in Estonia, while a serious sociological study conducted in 2002 found that $11 \%$ of Estonians had a liking for Maavalla Koda, or the "Estonian traditional religion" (Kõiva 2016: 64-77; see also Trifonov 2006). Obviously, the pre-Christian faith poses a much greater concern for Estonians than Lutheranism or Orthodox Christianity (which is traditional for the territory where the Seto tribe lives, and for some islands in the Baltic Sea). In spite of the bans imposed by the Lutheran Church, and later also of the disapproval expressed by the Soviet authorities (during that period, the organisation functioned illegally) and the victimisation of the "old faith" after the democratic changes in some areas (for example, Hiiumaa, where the religious field is occupied by Baptists), neo-paganism was revived along with the independence of the country.

The link between neo-paganism (considered within the paradigm of new religious movements) and nationalism, which is emphasised in the definitions of this phenomenon, is also well-known. V. Schnirelman defines neo-paganism as a nationwide religion, which is generated artificially by urban intellectuals from the fragments of ancient local beliefs and rituals with the aim "to revive national spirituality" (Schnirelman 1998: 3). As a rule, the main objective of such movements is considered to be the generation of the "new ethnic/national identity" (cf. definitions by Strimska 2005: 1-53; Aitamurto \& Simpson 2013: 1-9; Doyle White 2016, etc.).

It appears that the generation of this new national identity, influenced by the ideology of neo-paganism, has been quite successful. It is obvious that it supports the identity of not only $11 \%$ of the population of Estonia, but of some migrants that circulate between Estonia and the countries of Northern Europe and Great Britain. Neo-paganism determines the attachment to one's home locality, inhabited by one's own, at times individual spirits and deities. My interview demonstrates the neo-pagan beliefs of one migrant, and shows that this is one of the reasons that makes Estonians choose mobility over immigration (as the studies of the mass emigration of Estonians to Finland have shown). 
This example also reveals a new theoretical perspective. It appears that it is not only the urban elite who accepts "authentic religion". Obviously, this case represents a new trend in the development of nationalism, where the latter is no longer the creation and practice of national elites (Gellner 1999 [1983]), but the spirituality of "ordinary people". The opposition between global and national is already taking place at the level of elites and ordinary people. Nationalism is developing among the latter as a form of resistance and opposition to transnational authorities, transnational businesses, and transnational bureaucracy.

Within the framework of this topic, it is essential to point out that the Estonian case demonstrates the structuring of identity, in which folklore (and pseudofolkloric) sources predominate. These perceptions are becoming determinant under the conditions of migration so much that the conservative worldview / model of the world, enclosed within the framework of tradition (island isolation should also be taken into account), is becoming the basis for a more successful migration model, i.e., circular mobility, linked to faith in local spirits and deities, which are only available in one's homeland.

\section{Acknowledgements}

Research and fieldwork was done within the framework of the bilateral project, Folklore Traditions in Cultural and Social Discourse of Bulgaria and Estonia, coordinated by Ekaterina Anastasova from the Institute of Ethnology and Folklore Studies with Ethnographic Museum at the Bulgarian Academy of Science, and Mare Kõiva from the Estonian Literary Museum.

\section{Notes}

1 For example, see the bibliography of migration studies in Bulgaria by Mancheva \& Troeva 2011; theoretical perspectives of migration studies can be found in Krasteva 2014. See Marushiakova \& Popov 2013: 11-34, who consider the ethnographic approach in the research of the phenomenon of migration.

2 In Bulgarian literature, the term diaspora (with relevant specifications, i.e. traditional, socialist, etc.) is used to denote different waves of migration. For the purposes of this article, it is essential to point out that in the Baltic States (and not only), the term diaspora covers emigration before and immediately after the Second World War. Hereby I am using this term with its Bulgarian connotations. 
3 For multiculturalism and interculturalism, see Alonso-Ponga \& Pena Castro 2016: 52-63.

4 Under the socialist regime, migration "to the East" was determined by the so-called Iron Curtain:

- a risky escape into the "free world";

- $\quad$ expulsion from the homeland for dissident manifestations;

- limited options for legal emigration for the purpose of pursuing personal and professional ambitions and aspirations (marriages with foreigners, labour emigration by invitations, for highly qualified specialists).

After the democratic changes took place, migrations have been determined by a symbolic shift of the Iron Curtain from the Socialist Bloc to the West (access to the Schengen zone and the European labour market; white/black lists of the states in/outside the EU, etc.). Labour migration in search of a "normal life", which is impossible under the conditions of economic recession, social instability, and political cataclysms in postsocialist countries, prevails.

5 Highly qualified professionals that manage to find prestigious jobs in the recipient country.

6 Emigrants that find low-skilled jobs, quite often notwithstanding good education and qualifications (sometimes they come across as blue-collar workers).

7 Quite often they are contingent on the „light at the end of the tunnel“ in the donor state, as interviews with Bulgarians voting abroad (BNT, 2016) in the last election in Bulgaria (2016) have demonstrated.

8 See Anastasova 2017: 228-240.

9 U. R., about 40, higher education, Tallinn, December 2016, private conversation.

10 Estonia is referred to as the "Baltic tiger", or the "fifth Scandinavian country". In the 2000s, Estonia had the lowest debt (13\% of the GDP), and in 2011 it entered the Eurozone (according to data provided by the Eurostat agency).

11 See, for example, the memories of an Estonian diplomat who talks about an upsetting image of the first years of democracy: "I opened the fridge, and there were only a couple of yoghurts left. We went through a lot of difficulties" (M. M., female, higher education).

12 Chocolates with the pictures related to socialism, for example, Leonid Brezhnev and sunflowers (this crop was believed to be especially abundant during his rule). By the way, the "Soviet fashion" started after M. Gorbachev's Perestroika, and is widespread throughout the world.

13 It is worth mentioning that in the period of 1950-1980, Estonia was a country accepting emigrants (mainly from other republics of the USSR), while in 2000-2011, 
it was accepting emigrants from Finland, Great Britain, the USA, and Russia (people of Estonian origin born abroad) (see https://www.stat.ee/phc2011, 12.12.2016).

14 Data cited from Eesti Statistika (Estonian Statistics), Population by sex and age group, 1 January (see http://andmebaas.stat.ee/Index.aspx?lang=en, 23.04.2017).

15 The notion of circular migration (similarly to "pendulum-type" migration, circular migration is transboundary, while the "pendulum" is related to regional migrations, like town - village) has been covered in a number of articles, and several attempts to define it have been made. Cf. Skeldon 2012 and lit. quot.; Krasteva \& Otova \& Staykova 2011; UNESCO 2007 (see http://unesdoc.unesco.org/images/0015/001557/155779R. pdf, 15.12.2016).

16 Economic Commission for Europe. Conference of European Statisticians. $62^{\text {nd }}$ plenary session, Paris, 9-11 April 2014. Point 4 of the preliminary session agenda Measuring transborder mobility between Estonia and Finland with the aid of collecting data by means of mobile positioning. Prepared by Statistics Estonia and the Board of Statistics of Finland (see http://www.cisstat.com/BigData/CIS-Big\%20Data_05\%20 UNCES\%20Estonia_Finland-migration.pdf, 15.12.2016).

Also see http://www.unece.org/fileadmin/DAM/stats/documents/ece/ces/2014/ ECE_CES_2014_30-Estonia__Finland-Migration.pdf, 15.12.2016).

The data, collected by means of mobile positioning, is an analysis of the relocation of mobile phones provided and analysed by mobile network operators from Estonia and Finland.

This method is suitable for such highly technological states as Estonia and Finland, since both countries hold leading positions in the field of IT technologies. On the other hand, the custom of changing SIM cards when moving from one country to another makes it difficult to carry out research, as has been pointed out by the authors of the report (p. 13).

17 Muhu is the third largest island in Estonia (after Saaremaa and Hiiumaa). This is a part of the Moonsund archipelago in the Baltic Sea. The population of the island is 1,600 people.

18 The name of the respondent has been changed for ethical reasons.

19 Here I only present my observations from Muhu Island during my brief stay in 2013. More about religion and religious processes in Estonia see in the works of T. Jonuks, E.-H. Västrik, R. Ringvee, etc.

20 Kristjan Jaak Peterson (1801-1822), Estonian poet. His translation from Swedish to German of Finnish Mythology by Christfried Ganander (1789) was published in 1822, after the death of the translator. 
21 Christfried Ganander (1741-1790), Finnish folklorist, writer, linguist, author of the dictionary of the Finnish language (more than 30,000 words - Nytt Finsk Lexicon, 1787), and pastor. Finnish Mythology (Mythologia Fennica) was published in 1789.

22 On the basis of the examples from Finnish mythology, Friedrich Robert Faehlmann (1798-1850), an Estonian writer and doctor, gave birth to the idea of the Estonian epic poem Kalevipoeg (Kalev's Son). In 1844 he published a collection of folklore and mythological stories in German. He described the pantheon of deities (the supreme deity Vanemuine, and others). By means of schools and newspapers those stories became very popular.

23 For detailed information about the history, features, organisation, structure, goals, and events of Maavalla Koda, see http://www.maavald.ee/en/about-maavalla-koda (12.12.2016).

\section{References}

Aitamurto, Kaarina \& Simpson, Scott 2013. Introduction: Modern Pagan and Native Faith Movements in Central and Eastern Europe. In. Kaarina Aitamurto \& Scott Simpson (eds.) Modern Pagan and Native Faith Movements in Central and Eastern Europe. Durham: Acumen, pp. 1-9.

Alonso-Ponga, Garcia A. \& Pena Castro, M. J. 2016. Ot bulgari kam evropeytsi: belezhki varhu interkulturalizma, lokalizma I identichnostta [From Bulgarian to European: Remarks on Interculturality, Localization and Identity]. In: E. Anastasova (comp.) Bulgarski folklor. Identichnosti - religii - migratsii [Identity - Religion - Migration], I (5), pp. 52-63.

Anastasova, Ekaterina 2008. Vavedenie. Na tihiya sin Dunav [Introduction. The Quiet Son of the Danube]. In: E. Anastasova \& E. Grancharova \& M. Lubenova (eds.) Bulgarski folklor. Traditsii, obshnosti, identichnosti, 1 (5), p. 10.

Anastasova, Ekaterina 2017. Identichnost i migratsia 2. Amerikanskiyat slutchay [Identity and Migration. American Case]. Bulgarska etnologia, 2, pp. 228-240.

Doyle White, Ethan 2016. Wicca: History, Belief, and Community in Modern Pagan Witchcraft. Brighton, Chicago \& Toronto: Sussex Academic Press.

Gellner, Ernest 1999 [1983]. Natsii i natsionalizam [Nations and Nationalism]. Sofia: Panorama.

Gossiaux, Jean-François 1996. Un ethnicism transnational. La résurgence de l'identité valaque dans les Balkans. In: Daniel Fabre (ed.) L'Europe antre cultures et nations. Paris: MSH, Collection Ethnologie de la France, pp. 191-198.

Kõiva, Mare 2016. Poklonnichestvoto v sekulariziranoto obshtestvo - vazrazhdane i osobennosti [Pilgrimage in Secualrized Society. Invention and Special Features]. Bulgarski folklor, 1, pp. 64-77. 
Krasteva, Anna 2014. Ot migratsiya kam mobilnost. Politili I patishta [From Migration to Mobility. Policies and Routes]. Sofia: NBU.

Krasteva, Anna \& Otova, Ildiko \& Staykova, Evelina 2011. Vremenna I tsirkulyarna migratsiya [Temporary and circular migration]. EMM. Available at https:// annakrasteva.wordpress.com/2011/03/10/temporary-circular-migration/, last accessed on 05.12.2016.

Levitt, Peggy \& Jaworsky, B. Nadya 2007. Transnational Migration Studies: Past Developments and Future Trends. Annual Review of Sociology, Vol. 33, pp. 129-156.

Mancheva, Mila \& Troeva, Evgenija 2011. Migratsii ot i kam Bulgaria: Sastoyanie na izsledvaniyata [Migrations from and to Bulgaria: State of research]. In: Marko Haidinjak (comp.) Migratsii, pol i mezhdukulturni vzaimodeystviya v Bulgaria [Migration, Gender and Intercultural Interactions in Bulgaria]. Sofia: IMIR, pp. 17-67.

Marushiakova, Elena \& Popov, Veselin 2013. Etnologiya i migratsionni izsledvaniya [Ethnology and Migration Studies]. In: Mila Maeva \& Sofia Zahova Etnografiya na migratsiite [Ethnography of Migrations]. Sofia: Paradigma, pp. 11-34.

Penchev, Vladimir 2016. Bulgari v chuzhbina ili za topologiyata na bulgarskoto prisastvie [Bulgarians Abroad or the Topology of the Bulgarian Presence]. In: Ongal, VIII (12), pp. 1-7. Available at http://www.spisanie.ongal.net/broi12/2_Vladimir_ Penchev.pdf, last accessed on 01.12.2016.

Schnirelman, Victor A. 1998. Neoyazychestvo i natsionalizm (vostochnoevropeyskiy areal) [Neo-Paganism and Nationalism (Eastern European Area)]. Issledovaniya po prikladnoy i neotlozhnoy etnologii [Research in Applied and Current Ethnology], No. 114. Moskva: IEA RAN.

Skeldon, Ronald 1992. On Mobility and Fertility Transitions in East and Southeast Asia. Asian Pacific Migration Journal, Vol. 1 (2), pp. 220-249.

Skeldon, Ronald 2012. Going Round in Circles: Circular Migration, Poverty Alleviation and Marginality. International Migration, 50 (3), pp. 43-60. DOI: 10.1111/j.14682435.2012.00751.x.

Strimska, Michael F. 2005. Modern Paganism in World Cultures: Comparative Perspectives. Santa Barbara \& Denver \& Oxford: ABC-Clio, pp. 1-53.

Trifonov, Alexandr 2006. Religiya i SMI. - Religare: Estonia teryaet hristiyanskuyu identichnost'. Desyatay chast' naseleniya uzhe prinyala yazychestvo. [Religion and Media. - Religare: Estonia Is Losing Its Christian Identity. One Tenth of the Population Has Already Adopted Paganism]. Baznitsa info, Christian Media Group. Disput, 28.08. Available at http://baznica.info/article/religare-estoniyateryaet-khristianskuyu-i/, last accessed on 04.12.2016. 
UNESCO 2007 = Pécoud, Antoine \& Guchteneire, Paul de (eds.) 2009. Migratsii bez granits (Esse o svobodnom peredvizhenii ludey) [Migrations Without Borders (Essay on the Free Movement of People]. Available at http://unesdoc.unesco. org/images/0015/001557/155779R.pdf, last accessed on 12.12.2016.

Vukov, Nikolai 2009. "Meden gligan”, "bronzov voynik”, "kamenen voin” [“Copper Boar”, "Bronze Soldier", “Stone Warrior”]. In: Ekaterina Anastasova \& Iva Stanoeva (guest eds.) Bulgarski folklor. Balkanite i Baltika v Obedinena Evropa: istoriya, religii, kulturi) [Balkan and Baltic States in United Europe: History, Religion, and Culture], 3-4, pp. 58-65.

Zaiceva, Anzelika \& Zimmermann, Klaus F. 2008. Scale, diversity and determinants of labour migration in Europe. Oxford Review of Economic Policy, Vol. 24 (3), pp. 427-451.

Zelinsky, Wilbur 1971. The Hypothesis of the Mobility Transition. Geographical Review, 61 (2), pp. 219-249.

\section{Internet Sources}

Maavalla Koda. Available at http://www.maavald.ee/en/about-maavalla-koda, last accessed on 12.12.2016.

Measuring cross border mobility between Estonia and Finland with Mobile Positioning Datasets 2014. Economic Commission for Europe. Conference of European Statisticians. Available at http://www.unece.org/fileadmin/DAM/stats/ documents/ece/ces/2014/ECE_CES_2014_30-Estonia__Finland-Migration. pdf, last accessed on 15.12.2016; same in Russian http://www.cisstat.com/ BigData/CIS-Big\%20Data_05\%20UNCES\%20Estonia_Finland-migration.pdf.

Ots, Anu 2013. Bol'šinstvo èmigrantov po-prežnemu uezžajut v Finljandiju [Most Emigrants Still Leave for Finland]. In: Rezul'taty: perepisano 1294455 postojannyh žitelej [Results: 1,294,455 Permanent Residents Registered]. Available at http://www.stat.ee/press-reliz-2013-062, last accessed on 12.12.2016. 